\title{
GEOGRAPHICAL ASPECTS OF INDUSTRIAL TRANSFORMATION IN THE CZECH REPUBLIC
}

V. Toušek, M. Vančura, M. Viturka: Geographical Aspects of Industrial Transformation in the Czech Republic. - Geografie - Sborník CGS, 105, 2, pp. 155 - 165 (2000). The share of industrial production on GNP has been decreasing over the 1990s in the Czech Republic and, in the same time, a branch restructuring took place. The industrial transformation is accompanied by a decline of labour force and an increase of unemployment. Better situation has been observed in the regions with an inflow of foreign capital. The article deals with the significant role of direct foreign investments for the regional development. The analysis of investment localization is linked with the theory of development polarization.

KEY WORDS: industry - transformation - foreign investments - development polarization.

\section{Introduction}

The article deals with regional changes in the distribution of the Czech industry and its branch restructuring in 1990s. Some industrial companies belong to a group of attenuation branches (e.g. metallurgy, heavy machinery, textile and leather industries) with great release of workers. On the other hand, new branches have been emerging. They are characterized by an increase of production and its productivity and also by creation of new job opportunities (in particular electronics and automotive industry). The difference in development of individual branches has a great influence on the situation on labour market in different regions of the Czech Republic. Direct foreign investments play an important role in creating new jobs in industry. The authors analyse the direct foreign investments in a complex of 79 towns throughout the Czech Republic. Focus is particularly put on the impact of these investments on regional development.

\section{Industry before 1989}

The Czech Republic has a long industrial tradition. A significant part of industrial capacities of the former Austro-Hungarian Empire was built in Bohemia and Moravia. Besides traditional branches (food processing, textile industry, wood processing and glass industry) it was especially coal mining, metallurgy, manufacturing of building materials and dynamic machinery that developed before World War I. The interwar period was characterized by increased dynamics of the industrial production as a whole and by access to world markets in a newly formed Czechoslovakia.

After World War II, great deformations in industrial production as well as in the whole economy occurred as a result of the communist coup d'état in 
1948. Some deformations were already obvious during the War resulting from the necessity to meet the German war needs. The central government favoured large industrialization focusing especially on extensive development of heavy industries with extremely high demand of material and energy.

The industrial production in Czechoslovakia after 1948 was characterized by central control and directive planning and by absence of private companies. The technology failed to keep pace with the technologies of developed countries. Many enterprises suffered from overemployment, which considerably affected (together with other demotivating factors) the low productivity in general. The system of state property and central planning together with orientation to less demanding markets of the COMECON and other socialist countries did not press industrial factories to increase the efficiency and rationalize production. In the end of the 1980s the former Czechoslovakia statistically showed one of the greatest industrial potentials in the world per capita; the quality and structure of production, however, were far behind.

The industrial base in the late 1980s differed extremely in the branch structure when compared with average EU countries. It was affected by ideological preferences of those days, favouring development of heavy industry. The essential feature of the branches profiting from the socialist industrial policy was the orientation towards meeting the needs of the COMECON market less than the needs of the national economy. The high priority branches (e.g. nuclear energy production, metallurgy, machinery, heavy chemistry) were supplied by more labour force, more investments and also imports from the so-called hard currency areas. In the 1980s, the demands for capital in the priority branches restricted, to a greater degree, realization of structural changes. The industrial base was mostly represented by large companies; on the other hand there were only few small- and medium-sized enterprises.

In 1989 there were more than 2.1 million persons employed in industry, i.e. roughly 40 percent of all labour force in the Czech Republic. One third of industrial employees worked in machinery and metal industry - figure that well indicates the branch orientation of the Czech industry. Second in rank was fuel and power industry (nearly 300,000 employees); very close to this number were textile, clothing and leather industries. Around 150,000 persons worked in metallurgy, food processing and electronics. More than 100,000 persons were employed in chemical industry.

High concentrations of industrial labour force were found especially in the areas of coal mining and metallurgy. The most industrialized area (measured by the amount of industrial labour force) was the present region of Ostrava (334,700 employees) where the rate of workforce in industry exceeded 50 percent of all labour force. Similarly high figures were recorded in 13 districts; in the Karviná district (Ostrava region) the rate of industrial workforce was even 61.4 percent. On the other hand, in eight districts and in the capital city of Prague there were less than 30 percent of industrial employees. The lowest figures were recorded in Prague (24.5 percent) due to a high employment rate in a tertiary branch. A low degree of industrialization was also evident in most border districts neighbouring with former West Germany and Austria where restriction of industrial production took place as a result of expulsion of the German-speaking population after 1945 followed by the "Iron Curtain" effect. The districts located in hinterlands of big cities where many people commuted to the cores of big urban centres were characterized by a low number of industrial workforce. 


\section{Industrial Development after 1989}

The reform strategy since 1990 aimed at transition from a centrally planned economy towards a market economy. It required a complex approach including chronology of a broad spectrum of measures focusing on liberalization of prices, liberalization of foreign exchange controls, introduction of inner convertibility of currency, and privatization. The degree of success depended, to a certain extent, on their complexity and quick succession.

The economic reform started with liberalization of prices and foreign exchange controls in January 1991. In the same year a sharp fall of GNP was recorded (by 11.5 percent in total); the industrial production went down even by 22 percent. There were two main reasons for this fall. First, it was the loss of traditional eastern markets (COMECON was abolished) - many industrial enterprises lost an essential part of their foreign markets. Second, after the liberalization of prices in 1991 the prices escalated by 57 percent on average; the nominal incomes, however, grew only by 7 percent. The decrease of real incomes resulted in a great decrease of consumers' demand. After 1992, the consumption, investments and export started to grow again.

Privatization (in particular privatization of industrial enterprises) was the core of economic transformation. It consisted of three programmes: property restitution, small-scale privatization and large-scale privatization. The restitution process enabled to return the nationalized property to former owners (nationalization took place after 1948). The small-scale privatization dealt with small economic units, e.g. shops, restaurants, and small industrial workshops, which were sold in auction. The most important privatization program was the large-scale privatization the aim of which was to transform key enterprises into private subjects.

The large-scale privatization combined several privatization techniques. The small-sized enterprises were usually sold in auction or in tenders, while most medium-sized and large companies were transformed into joint stock companies. The stocks were distributed to all Czech citizens over the age of 18 in the form of vouchers (e. g. voucher privatization). It comprised nearly one half of the total number of stocks of the privatized companies. The nature of privatization and its speed differentiated the privatization in the Czech Republic from privatization processes in other transitive economies. The privatization process was different and specific even in comparison with the process that occurred in those advanced countries where governments decided to privatize selected state-owned large industrial enterprises. While in the western countries the privatization took place in a market environment, in the Czech Republic market rules were yet to be created. Another difference was the enormous inequality between the volume of the property to be privatized under the market conditions and the volume of domestic savings. Due to this fact, it would have taken dozens of years to sell the state property to Czech investors. The priority of the Czech privatization process was not to increase the efficiency of individual enterprises as it was common in market economies, but to create a structure of private owners.

The opening of the Czech market towards foreign producers and expanding exports of Czech production to advanced foreign markets provided a challenge for the Czech industrial enterprises to assert themselves in a competitive environment. To be able to survive, restructuring became inevitable. The most significant aim of industrial restructuring in the Czech Republic was to increase the competitive strength of companies. 
The voucher privatization in the Czech Republic was accomplished in 1994. In comparison with the other former Communist countries, in the Czech Republic the greatest share of private property was reached. The state held the majority of stocks, later these were sold to strategic investors, in particular to foreign investors. The process of privatization in the Czech Republic was regarded rapid only in the sense that the former owner - i. e. the state - was replaced by new private owners - i.e. by millions of "voucher" shareholders and investment privatization funds which were neither able nor ambitious enough to control and restructure the companies. Most of voucher shareholders sold their stocks, as did most of the investment funds, too. Many new owners (also in firms that did not emerge in the process of voucher privatization) started to misuse imperfect laws and robbed the property of their own companies. These facts turned out to be the weakest parts of the "Czech way" of privatization.

Some privatization projects failed to succeed. The expected restructuring of the production in a number of privatized companies did not bring desired results. On the contrary, many companies that were in debt were declared bankrupt or their debts were paid by the state. According to some economists, there should have been more foreign capital participation in the privatization process.

The share of industry on GNP has been steadily declining. While in 1990 industrial production accounted for more than 41.6 percent of GNP, in 1999 it was only 36.8 percent. Czech industry in the $1990 \mathrm{~s}$ is also characterized only by a decline of workforce. This decline differs by branches and by regions. The most recent data, however, are accessible for the year 1996 (the Czech Statistical Office). The number of industrial employees in the period of $1989-1996$ decreased by more than 500,000 people. The largest decrease in industrial labour force was recorded at the beginning of the transformation period. In 1991 the number decreased by more than 200,000 and in 1992 by more than 100,000 . Based on the labour force sample survey, less than 1.5 million people work in the Czech industry at the moment. A comparatively high decrease of labour force can be observed in mining and leather industry. In both branches worked less than one half of the workforce compared with the end of 1989. A dramatic decline (by more than one third) was recorded in machinery and metal industry. In manufacturing of building materials, textile and clothing industries, metallurgy, and manufacturing of glass, china and ceramics the number of employees decreased by one fourth. In chemical industry, the decrease was more than 10 percent. A slight increase of workforce occurred in electronics, food processing, wood and paper processing and printing industry.

The largest decrease of labour force occurred in the coal mining regions of Ústí nad Labem and Ostrava. The employment rate here compared to 1989 was less than 70 percent; the same situation was observed in the regions of Central Bohemia, Liberec, and Brno. The least important changes in the number of industrial workforce were in the region of České Budějovice (decrease by 8.7 percent only.)

More distinct differentiation can be seen on a district level. In some districts the number of people working in industry decreased by 50 percent; on the contrary in other districts even increases have been recorded (Figure 1). The latter is the case of the district Plzeň-south where a number of new (mostly German) industrial companies emerged. On the other hand, in the districts of Kladno and Pŕibram the labour force in industry declined by more than a half. 


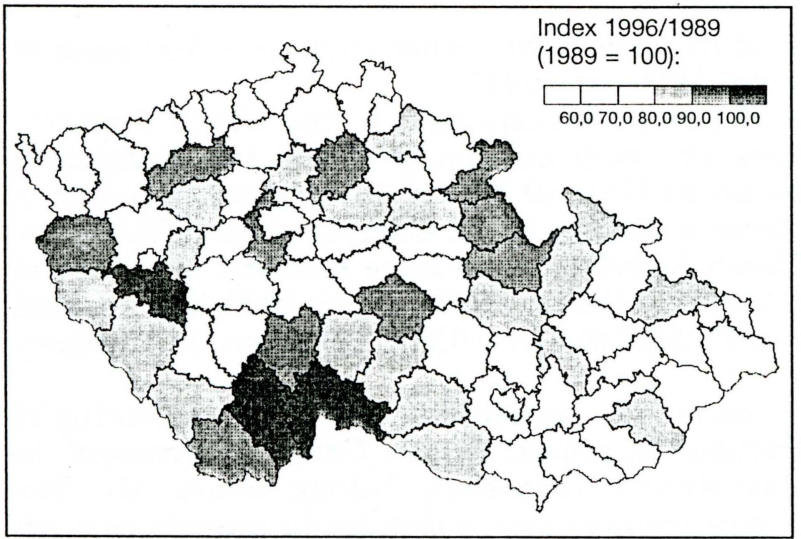

Figure 1 - Changes in industrial employment (1989 1996). Source: Czech Statistical Office 1990, 1997.

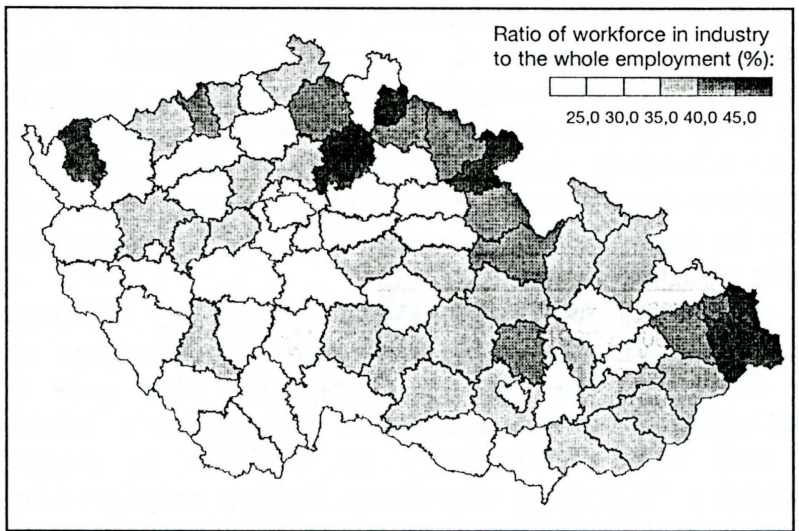

Figure 2 - Labour force in industry (December 31, 1996). Source: Czech Statistical Office 1997. and engineering. On the other hand new jobs were created - to a large extent by foreign investments, in particular on green field sites.

\section{Foreign Capital in the Czech Republic}

The flow of foreign direct investment (FDI) is vital for a transforming economy. Besides providing stability and enabling to finance the current deficit it also accelerates industrial restructuring, creates new jobs and increases competitiveness of the whole economy. The volume of foreign investment often serves as an indicator of the progress during the economical transition.

Foreign direct investments were proclaimed legal in the Czech Republic in 1989. Certain restrictive conditions were imposed on joint companies. The foreign capital was allowed to own not more than 49 percent of a joint company and it was due to a governmental approval. A new act on foreign- 
backed companies was amended in April 1990 authorizing up to 100 percent foreign ownership (Brada, Clavel, Wienert 1994).

In 1998, the total amount of foreign investments in the Czech Republic reached USD 2.5 billion. Since the very beginning of the transformation process the flow of FDI has exceeded USD 10 billion (investment in industry was nearly 60 percent of all foreign investments). Compared with Poland or Hungary it seems that the Czech Republic could have received more of the whole volume of foreign investments. (Carter 1999). Since 1999, the amount of foreign direct investments in Poland was over USD 22 billion, in Hungary USD 17 billion.

The present growth of investment was particularly due to the launching of the Investment Incentives Package approved by the Czech government in May 1998. To important investment incentives belong above all "tax holidays", duty-free import of new technologies, subsidies to provide new job opportunities and re-training allowances. The active policy of investment was used in many countries but the Czech Republic failed to keep pace for a long time; instead, the natural advantages of the Czech Republic (highly skilled labour force, social stability, and geographical position) were emphasized. To attract more foreign investments, however, it was not sufficient. The Investment Incentives Package has already brought first results. The positive feature of new investments is their flow to electrical engineering, electronics and automotive industry, i.e. branches using hi-tech. Even though it is workers' profession that is of prime importance, it is expected that in some of the enterprises there will also be established research centres with new job opportunities requiring specific technical qualifications.

Most of FDI have been aimed at food processing (including tobacco industry), machinery (especially automotive industry) and manufacture of building materials. In some branches the foreign companies play now a dominant role. Foreign capital controls cement and brick manufacture, takes a dominant part in glass and ceramic industry as well as in sugar manufacture and brewery industry. The most important foreign employer in the Czech industry is Volkswagen (Škoda-Auto employs 22,000 persons). $\mathrm{ABB}$, Siemens, Bosch, Ford, and AVX Corporation have entered the Czech territory, too. Philip Morris, Danone, Nestlé, SAB, Unilever, etc. operate in food processing and tobacco industry. In chemical industry there is the IOC consortium (Shell, Agip, Conoco), in glass industry Glaverbel and SaintGobain, in manufacturing of building materials - Lasselsberger, Wienerberger and Heidelberg Zement.

\section{Analysis of Foreign Direct Investments and Its Consequences}

The major role of foreign direct investment in the regional development is clearly manifested in the spatial analysis, which included 79 of the most important towns (with 47 percent of the total population in the Czech Republic). The analysis dealt with 3,733 foreign-backed companies operating in manufacturing, distribution and productive services with nearly 10 percent of the labour force in towns. The foreign-backed companies employed 116,000 people in Prague (first in rank), 23,000 in Mladá Boleslav, and 15,000 in Brno. More than 5,000 people worked in such companies in Plzeň and České Budějovice. 963 foreign-backed companies (i.e. 26 percent of the analysed group) were doing business in manufacturing, representing more than one 
fifth of the workforce in industry. Manufacturing companies operated mostly in towns with less than 50,000 inhabitants; in bigger towns and cities there were foreign-backed companies that operated in distribution and productive services. These data correspond to the data collected by CzechInvest (agency supporting direct foreign investment to the Czech Republic) which realized a survey in industrial foreign-backed firms (Pomery 1998).

In the end of 1998 there were nearly 800 foreign industrial companies with 50 or more employees in the Czech Republic. These companies employed more than 250,000 people. The biggest concentration of these firms can be seen in Western Bohemia; on the other hand in Northern Moravia there were just a few of them. Foreign industrial companies account for at least 5 percent of the total employment not only in Prague but especially in the region of Liberec (around 9 percent) and in Central Bohemia, Plzeň, Jihlava, and České Budějovice. On the contrary, in the region of Ostrava it is only 1,7 percent. The significance of foreign companies for the total employment, however, is much greater. The foreign-backed industrial companies are in contact with 10,000 Czech-owned suppliers from the production sector, distribution and productive services. These supplier firms employ around half million people. The share of foreign-backed companies of the whole number of industrial firms with more than 5 employees is shown in Figure 3.

Foreign investments have positive impacts not only on access to the most advanced markets but also on changes in the microeconomical environment. The degree of foreign investments can be considered a basic indicator of the level of globalisation of economy from both macroeconomical and regional viewpoints. This premise can help design strategies for the regional development.

It is the polarization theory that is used as a theoretical background of the strategy in question. It emphasises positive results of the development in selected settlement centres designed as development poles. These poles comprise the so-called driving units (e. g. large industrial enterprises) or a set of driving activities (e.g. concentration of productive and other services) whose economical growth is a crucial dynamic factor of the regional development. The theory of polarized development is a link between a theory of localization and that of economic growth. The complexity of the theory of polarized development consists in analyzing and synthesizing endogenic factors of regional development as well as exogenic ones. This theory is compatible with the theory of centres, which deals with size and functional hierarchy of towns as the economical development tends to be top-down.

Practical application of the theory of polarized development starts with identification of regions that are open to an accelerated economical development, that have developed development poles and consequent development axes (dominating regions). Their opposites are regions without development poles that are not integrated with dominating regions by means of development axes. Their development is often characterized by low or even negative developmental dynamism (undeveloped regions). Between these two opposites there are regions linked to dominant regions by means of development axes (integrated subdominant regions). The evaluation methodology (see Viturka et al. 1998), applying nodal regions of selected towns of the Czech Republic as basic territorial units, emphasises the role of foreign investment in global competitiveness of individual regions. Putting the region in a corresponding type (a hypothesis was supported that the position of development pole or development center determines even the position of a corresponding nodal 


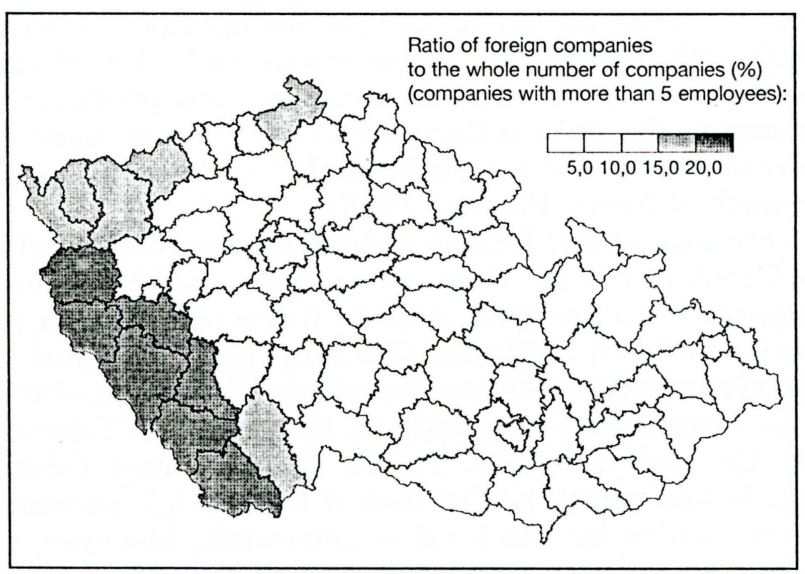

Figure 3 - Industrial companies with foreign capital (December 1998). Source: Czech Statistical Office 1998.

optimum scenarios of their developmental strategy The regional development is significantly determined by competitiveness of industrial activities representing "condensation cores" (with other economic activities especially productive services).

Classification of the largest Czech cities based on evaluation of selected economic activities is shown in Figure 4.

Development poles. Types of development poles: A - development poles of international significance (Prague, Brno), B - development poles of national significance (regional centres excluding Jihlava and including Mladá Boleslav), C - perspective development poles, i. e. other regional centres that do not fit the criteria of development poles (Jihlava).

Sub-types of development poles: A1 - main development pole, A2 secondary development pole, B1 - fully developed pole, B2 - partly developed pole, B3 - little developed pole.

Sub-dominant (and/or sub-regional) development centres: Types of subdominant development centres: I - the most important development centres, II - important development centres, III - smaller centres attractive for investments.

Sub-types of subdominant development centres: I: 1 - centres with most attractive location, 2 - centres with very attractive location, 3 - centres with neutral location, 4 - centres with partly unattractive location (only within the framework of one branch, i.e. either in manufacturing - M, distribution - D, or productive service - S); II: 1 centres with partly attractive location (again three sub-types: M, D, S), 2 centres with neutral location, 3 centres with partly unattractive location, 4 centres with very unattractive location; III: 1 - smaller centres with more than 1,000 employees in foreign-backed companies, 2 smaller centres with less than 1,000 employees competing with superior centres (i.e. district towns) in the number of employees in foreign-backed companies.

Taking into account the strategies of regional development under the conditions of economic polarization, it is necessary to formulate several developmental scenarios considering potential chances of individual regions. Three basic scenarios of regional development can be defined: acceleration, stimulation and stabilisation. 


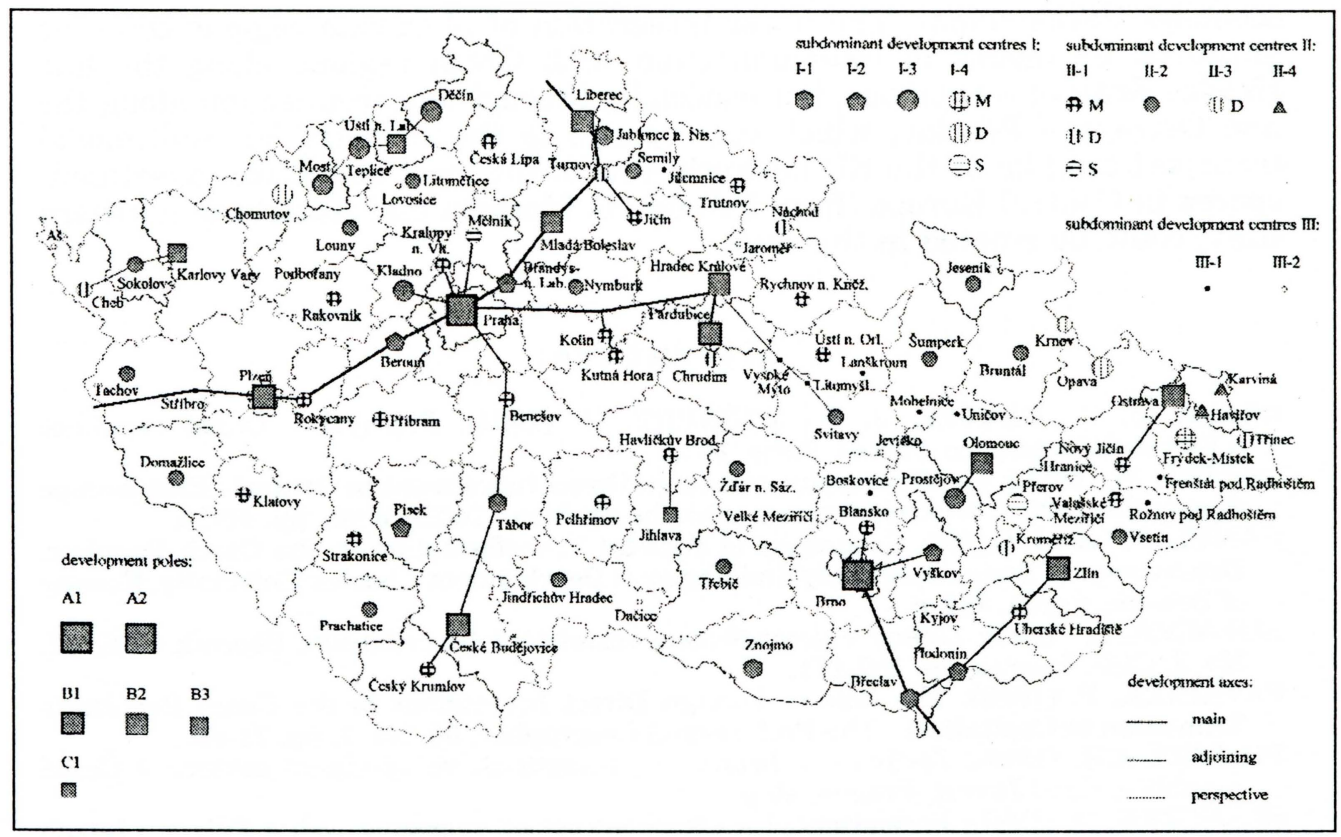

Figure 4 - Development polarization in the Czech Republic

Application of the acceleration scenario is an optimum strategy for the most important growth centres (structurally developed poles and development axes). Its characteristic feature is an offensive entrepreneurial "power politics" approach emphasising strong points of developmental opportunities. Application of a stimulation scenario appears to be a good developmental strategy, especially for economically exposed nodal regions with structurally undeveloped development poles and also for integrated regions linked to the main development axes (with a contingent structural combination with an acceleration developmental scenario) or secondary development axes, in selected cases also for unintegrated regions including centres with attractive location. The basic aspect of the stabilization scenario is the focus on reducing developmental risks by means of supporting Cupertino links with development poles where strong points are emphasized and weak ones suppressed. The application of the stabilization developmental scenario primarily aims at supporting the development of weakly integrated, economically marginal and/or structurally affected regions with centres with neutral or unattractive locations. In harmony with the long-term tendencies, such areas can be found especially in the regions of Ostrava and Ústí nad Labem, and/or in the region of Jihlava. The stabilization scenario requires a specific approach focusing on perspective supporting competitiveness by suppressing weak points and thus reducing the existing and potential developmental risks.

From the general point of view it is clear that regions in Bohemia enjoy a higher level of economic integration compared to Moravia. The key moment is the dominant position of Prague as a main development pole of international importance; consequently the regions situated along west and north-east Prague's development axes have the best future prospects as regards 
economic development. The lower integration of Moravian regions could be improved by means of interconnection with Czech regions along the line Hradec Králové - Olomouc, but especially through interconnection along the line Ostrava - Břeclav, which corresponds to the so-called VI multimodal transport corridor of the EU network. One of the most attractive investment spaces in Central Europe (from Poland via Moravia and Austria to northern Italy) could be created in this way.

\section{Literature:}

BRADA, J. C., CLAVEL, J. D., WIENERT, H. (1994): Průmysl v České republice a Slovenské republice. OECD, Paris, 163 p.

CARTER, W. (1999): The Geography of Foreign Direct Investment in Central - East Europe during the 1990's. Wirtschaftsgeographische Studien., 24/25, Wien, pp. 40-70.

HAMPL, M. et al. (1999): Geography of Societal Transformation in the Czech Republic. Department of Social Geography and Regional Development Charles University, Faculty of Science, Praha, 242 p.

KOPAČKA, L. (1992): Změny v geografickém rozmístění čs. průmyslu. Sborník ČGS, 97, No. 3, CGS, Prague, pp. 152-171.

PAVLINEK, P. (1998): The Role of Foreign Direct Investment in the Czech Republic's Transition to Capitalism'. The Professional Geographer, 50, No. 1, pp. 71-85.

POMERY, CH. (1998): Zpráva o zahraničních investicích ve výrobním sektoru v České republice. CzechInvest, Prague, $40 \mathrm{p}$.

SLENCZEK, M. (1997): Pochodzenie i wielkość inwestycji zagranicznych w Polsce w latach 1989 - 1996. Czasopismo Geograficzne, 68, No. 3-4, pp. 373-382.

ŠVEJNAR, J. et al. (1997): Česká republika a ekonomická transformace ve střední a východní Evropě. Academia, Prague, 360 p.

TOUŠ̃EK, V., VANČURA M. (1996): Aktuální problémy ČR. I. díl, Průmysl 1. část. Scholarium, Ostrava, $27 \mathrm{p}$.

VAN HASTENBERG, H. (1996): Regional and Sectoral Characteristics of Foreign Direct Investment in Hungary. In: Workshop Transformation Processes in Eastern Europe, ESR/NWO, The Hague, pp. 121-136.

VITURKA, M. a kol. (1998): Investiční atraktivita vybraných měst České republiky. Ekonomicko-správní fakulta MU, Brno, 120 p.

\section{Shrnutí}

\section{GEOGRAFICKÉ ASPEKTY TRANSFORMACE PRŮMYSLU V ČESKÉ REPUBLICE}

Česká republika se v minulosti řadila mezi vyspělé země s rozvinutou průmyslovou výrobou. Začlenění Československa do "sovětského bloku“ v roce 1948 významně ovlivnilo odvětvovou strukturu průmyslu ve prospěch energeticky náročných odvětví a mělo v pozdějším období negativní vliv i na jeho technologickou úroveň. Prủmyslová výroba vázala vysoký počet pracovníků. Přechod od centrálně řízené ekonomiky k tržnímu hospodářství mj. vyvolal nutné uvolňování pracovníků, především v málo produktivních průmyslových podnicích. Intenzita uvolňování měla $\mathrm{z}$ hlediska odvětvové struktury selektivní charakter. Některá odvětví byla v podmínkách otevřené konkurence postižena více a oblasti s jejich větší koncentrací jsou vystaveny daleko větším tlakům zejména na trhu práce (strukturálně postižené regiony). Na druhé straně se míra nezaměstnanosti udržuje v přijatelných hranicích $\mathrm{v}$ regionech, do kterých směřuje ve větším rozsahu zahraniční kapitál. Z výhodné geografické polohy těží oblasti ležící v blízkosti bývalé „železné opony“. Př́mé zahraniční investice významně ovlivňují také hierarchii pólů rozvoje včetně subdominantních rozvojových center (determinujících i postavení př́islušných nodálních regionů) a utváření rozvojových os na území České republiky. Investice urychlují restrukturalizaci průmyslu, vytvářejí nová pracovní místa a zvyšují konkurenceschopnost celého hospodářství. Objem zahraničních investic může sloužit i jako indikátor pokroku ekonomické transformace $\mathrm{v}$ jednotlivých regionech. Poznatky získané regionální analýzou investic 
mohou napomoci objektivnějšímu přístupu při formulování variantních scénářů regionálního rozvoje.

Obr. 1 - Změny zaměstnanosti v průmyslu (1989 - 1996)

Obr. 2 - Pracující v průmyslu (k 31. prosinci 1996)

Obr. 3 - Podniky se zahraničním kapitálem podnikající v průmyslu (prosinec 1998)

Obr. 4 - Polarizační rozvoj na území České republiky

(V. Toušek is with Department of Geography, Faculty of Science, Masaryk University, Kotlářská 2, 61137 Brno, Czechia. M. Vančura is with Pedagogical fakulty, Jihočeská University, Jeronýmova 16, České Budějovice, Czechia. M. Viturka is with Faculty of Economy and Administration, Masaryk University, Lipová 41a, Brno, Czechia.)

Arrived to the editor's office on January 15, 2000 